\title{
PRE-CAMBRIAN FORMATIONS OF INDIA
}

SIR,-The paper by Professor Holmes on "The Age of Uraninite and Monazite from the Post-Delhi Pegmatites of Rajputana" (Geol. Mag., lxxxvi, 1949) is of much interest to all students of the pre-Cambrian formations of India. The wide areas covered by these formations in Peninsular India, the facts that there are several systems of such rocks, and that the continuity of exposure at the surface is interrupted by wide spreads of younger formations such as the Gondwanas and the Deccan Trap, make the correlation of the various separate exposures of these older formations a matter of much difficulty, a difficulty that is accentuated by the intensity of the metamorphism to which they have been subjected appearing to vary from one part of India to another.

Some years ago I began an attack upon this problem in a memoir entitled "An Attempt at the Correlation of the Ancient Schistose Formations of Peninsular India " (Mem. Geol. Surv. Ind., lxx, Part 1 (1936) ; Part 2, No. 1 (1936) ; and Part 2, No. 2 (1940)). The method adopted was to divide India into provinces for purpose of discussion, the arrangement proposed being given on page 42 of the work cited, where names are given to fifteen Archaean provinces for Peninsular India, with two provinces for Himalayan occurrences, and one for Burma, making eighteen provinces in all. The boundaries of these provinces are shown on an accompanying map. The intention was to discuss each of these provinces in turn. Those so far studied are :-

Province No. 1. Dharwar-Mysore-Nellore Province (loc. cit., pp. 53-116).

Province No. 2. Chanda-Bastar Province (loc. cit., pp. 117-156).

Province No. 3. Singhbhum-Orissa Province (loc. cit., pp. 157-217).

Province No. 4. Sausar-Balaghat Province (loc. cit., pp. 219-324).

The intervention of the war and other reasons have prevented the completion of this study, but the task has not been abandoned.

In the Introduction to the Memoir (Part 1, pp. 1-51), I have discussed the criteria to be used in this attempt at correlation. One of them is lead-ratios and helium-ratios (pp. 20-5), and it was hoped that the mention of this would incite students of the radio-active properties of minerals to come to the rescue of the stratigrapher struggling with the correlation of rocks devoid of fossils.

The studies made by Professor Holmes and others of such radio-active minerals as have been found in the Indian Peninsula are, therefore, very welcome.

But there are great difficulties in making use of such methods. The first difficulty is, of course, the degree of accuracy of the methods used in basing age determinations upon measurements of lead and other ratios. However, with the introduction of successive refinements and corrections the students of these methods are becoming increasingly confident of the value to be placed upon such determinations and there appears to be a sufficient degree of agreement between the broad results obtained by different methods to allow one to assume that the ages so determined must be accepted as rough approximations to the truth (usually within say 100 to 200 million years and often much closer).

The second difficulty in India is that the radio-active minerals available for study all come from pegmatites, so that whilst the results show the ages of the pegmatites, they give only the minimum ages of the rocks into which the pegmatites are intrusive. These rocks may be hundreds of millions of years older.

In Rajputana there are at least three systems of ancient stratified rocks, each with its own pegmatites. It is only pegmatites of the type intrusive into the youngest of these formations, namely the Delhi system, that have yielded radio-active minerals ; but the examples of these pegmatites that carry the minerals studied do not appear actually to cut the Delhis, but only the older gneisses and Aravallis : these pegmatites are thus post-Delhi only by inference. Assuming, however, that the post-Delhi attribution is correct then the uraninite and monazite derived therefrom discussed by Professor 
Holmes show that the Delhis are older than 700 to 865 million years. They also show that the rocks that these pegmatites actually cut, namely the gneisses and the Aravallis respectively, which are much older than the Delhis, are also older than 700 to 865 million years.

Professor Holmes also discusses the ages of the uraninite and monazite obtained from mica-pegmatites near Singar, Gaya district, Bihar, the answer being about 900 million years (830-960). These pegmatites cut schists included in my Narbada-Son-Bihar Province No. 6.

$\mathrm{He}$ also draws attention to two recent determinations in India of the apparent age of samarskite from the mica-pegmatites of the Nellore district, Madras, one determination giving 830 million years and the other 1,550 million years, these pegmatites cutting rocks regarded as Dharwarian, though this is not the type area of Foote. As Professor Holmes asks, it is desirable that the analysts responsible for these widely discrepant results should repeat their work.

Meanwhile we can summarize the results of determinations of the age of minerals in Indian mica-pegmatites as follows :-

$$
\begin{array}{ll}
\text { Rajputana } & \text {. } 700 \text { to } 865 \text { million years. } \\
\text { Gaya, Bihar } & \text {. } 900(830-960) \text { million years (or } 955 \pm 40 \text { ). } \\
\text { Nellore } & \text {. } 830 \text { and } 1,550 \text { million years. }
\end{array}
$$

Except for the second Nellore result these pegmatite minerals all give results between 700 and 960 million years.

The question for me in my task is whether these results help in the correlation of the ancients schistose formations of Peninsular India. I find it difficult at present to see what conclusion can be drawn from these data except that some of the pegmatites of Peninsular India range in age from 700 to 960 (or 1,550) million years. They give no information concerning the relative ages of the schistose formations of different parts of the Peninsula, nor do they show whether the data relate to pegmatites of more than one age, though this seems not unlikely.

Presumable Professor Holmes recognizes the truth of the last sentence, as he attempts to deduce the relative ages of the various schistose belts of the Peninsula by considering whether the strike of one belt cuts that of another. Thus, he deduces that the strike of the ancient rocks of the Satpura Range cuts across that of the Aravalli Belt, so that the Satpura rocks are the younger. I see no reason why the argument should not be used in the reverse manner to deduce that the Aravalli Belt is the younger, except that this type of criterion appears to have little weight. The strike of the Satpura Range is W.S.W. at its eastern end, curling to westerly as one proceeds westwards. The pre-Cambrian rocks of the Satpuras are then covered by Deccan Trap lavas for some hundreds of miles to the west. The strike direction shown on Professor Holmes' map in Text-fig. 1 marked "Satpura Range" does not represent any strike of the older rocks, as these are here covered by the Deccan Trap : any conclusion drawn from the fact that this black line on Professor Holmes' map is nearly at right angles to the Aravalli strike is therefore irrelevant. Instead, there is nothing, on the evidence available, to prevent one from holding the view that the ancient rocks of the Satpura Belt as they have continued westward beneath the Deccan Trap have also continued with their clockwise change of strike so as to emerge in the west from beneath the Deccan Trap with the Aravalli strike, now N.N.W., as exhibited by the Aravallis of Jhabua State, with their contained gonditic rocks. These latter may well be the western stratigraphical continuation of the gonditic rocks of the Sausar series in the Central Provinces on the eastern side of the Deccan Trap cover.

Professor Holmes also attempts to decide the relative ages of other schistose beits of the Peninsula, discussing specially the Satpura belt, the Eastern Ghats belt, and the Dharwar belt. In so far as he relies on his radio-active data in this discussion, his principal difficulty, though he does seem to know it, is that none of the determinations recorded by him relate to any one of

VoL. LXXXVII. -NO. 2 
these three belts. Reference to the map forming Plate I of my Memoir cited above shows that Gaya is not situated on my Satpura belt, being in my Province No. 6 instead of in Province No. 8, which runs from the Central Provinces through the Ranchi plateau on an alignment to the south of the Bihar mica belt, and not as shown on Professor Holmes' map. Further, the Nellore pegmatites do not cut rocks in my Eastern Ghats Province No. 15, or its continuation Province No. 12 near Nellore. Instead they lie in my Nellore-Mysore-Dharwar Province No. 1. Further, the strike of the schists and gneisses of Nellore cut by the pegmatites is N.N.W. to N.W., instead of N.N.E. as assumed by Professor Holmes. ${ }^{1}$

Thus, I think it would be wiser not to attempt to draw conclusions concerning the relative ages of the various belts of schists from a consideration of their general strikes. Instead, the only conclusion that can be drawn from these studies of radio-active minerals is that the gneisses and Aravalli schists into which the Rajputana pegmatites are intruded, the schists of the Bihar mica belt, and the schists and gneisses of the Nellore mica belt are all older than 700 to 960 million years.

As a result of his attempt to discuss the relative ages of various schist beits in India, partly on the basis of their strikes and partly perhaps on the basis of his radio-active data which as shown above do not apply, Professor Holmes writes concerning the relative ages of the Satpura and Eastern Ghats belts and the Dharwars : "In any case the Dharwars are older than both." This still remains to be proved. At present both Dr. Krishnan, ${ }^{2}$ to whose views reference is made, and $I$ hold the view that the Dharwars are of an age comparable with that of a portion of the schistose formation of Chota Nagpur and the Central Provinces, both of which lie on or to the south of the Satpura belt. This point has been discussed fully in Part 2, No. 2, containing my accounts of Province Nos: 1, 3, and 4, of the Memoir already cited, and the evidence now produced does not provide any reason for a change of the views there set forth. It may be unwise to use the term "Dharwar" away from its home in Southern India, but it is not wrong to attempt to correlate with the Dharwars the schistose formations of other parts of India. The presumption is that whilst Dharwar sediments were being deposited in Southern India sedimentation may also have been in progress further north. It may be judged from the above that I do not accept the broad sequence in the pre-Cambrian areas of India given by Professor Holmes on page 298 of his paper. His Satpura and Aravalli cycles may well be of the same approximate age. I prefer, however, not to deal with cycles and the relative ages of belts, but with the relative ages of the rock systems that form such belts.

With reference to the rocks of my Eastern Ghats Province it is sufficient perhaps to say that $I$ have not yet discussed this province in the Memoir cited above. The rocks of this province are all in the hypo-metamorphic grade (Geol. Mag., 1927, p. 332) of metamorphism : there are no amphiboles, no chlorite, no epidote, no micro:line, etc., over many hundreds of square miles of terrain. Instead : pyroxenes, biotite, garnet, sillimanite, and cryptoperthite; also charnockitic rocks, khondalites, kodurites, and other queer rocks. The rocks of this province are almost everywhere garnetiferous, and form the terrain the study of which led to my idea of an infra-plutonic zone in the earth's crust (Rec. Geol. Surv. Ind., xliii, p. 43, 1913, and Geol. Mag., 1914, p. 65). The correlation of a terrain of this high grade of metamorphism with schistose terrain' of the normal type elsewhere in India presents a problem of major difficulty. But I shall not be surprised if the correlation favoured in the end is of the marbles and manganese-garnetbearing rocks (kodurites) of the Eastern Ghats province with the marbles and manganese-garnet-bearing rocks (gondites) of the Central Provinces

1 The schists of Nellore do not belong to Foote's original belts of Dharwars, five in number, but are generally regarded as being probably of Dharwar age. See Fermor, loc. cit., p. 99.

${ }_{2}^{2}$ See Geology of India and Burma, Table 13, p. 144 (1949). 
and of Gangpur in Chota Nagpur, and thus also with the Aravallis of Rajputana, as I adumbrated many years ago.

I agree with Professor Holmes that it would be a pity to perpetuate in India a mistake that would be analogous to the misuse of the term "Laurentian" in North America." Let us hope that we shall succeed in avoiding such in India and that future field work will lead to the discovery of radio-active minerals in the older pegmatites, and will also reveal whether the post-Delhi pegmatites of Rajputana are of the same age as the micabearing pegmatites of Bihar and Nellore, or are younger. It would be very useful indeed if studies of radio-active minerals did in the end help the stratigrapher by giving him two datum lines in the ancient schistose formations of Peninsular India. At present $I$ prefer the manganese datum line, as exemplified by gondite (and perhaps kodurite) (see Mem. G.S.I., lxx, p. 17, 1936).

However, I do not wish to close this letter on a critical note, but instead to show the great value of the results obtained by Professor Holmes. The work of Dr. A. M. Heron and his party during many years in Rajputana (summarized in Trans. Nat. Inst. Sci. Ind., i, No. 2, 1935) has shown that the ancient schistose rocks of this terrain can be grouped into a succession of four systems, of which the Delhis are the youngest, and a gneissic complex the oldest. It is a splendid thing to know now that the age of the youngest part of this grand succession of unconformable systems is some 735 million years (using Professor Holmes' preferred value) or nearly 250 million years older than the base of the Cambrian. We must ask what stratified system, or systems, of rocks occupies this vast time interval, an interval roughly equal to that of the five Palaeozoic systems Cambrian to Carboniferous.

As a group name for the unfossiliferous formations lying uncomformably on the schists and gneisses of assumed Archaean age Sir Thomas Holland proposed the term Purana (meaning old or ancient), and this term is in current use in India (Trans. Min. Geol. Inst. Ind.,.i, p. 47, 1906; and Mem. G.S.I., li, pt. 1, p. 147,1926$)$. The term Purana corresponds roughly to the Algonkian, comprising the Keweenawan and Animikie systems of North America. To this group Holland assigned the Vindhyans and the underlying Cuddapahs, two great systems of stratified sedimentary rocks, as well as other formations thought to be their equivalents. It is unknown whether the upper part of the Vindhyans extends into the Cambrian, as is not unlikely, or whether the entire system, Upper and Lower, is of pre-Cambrian age. In either case it is shown by Professor Holmes' work that there is ample room in the time scale, in the gap above the Delhis, for both the Vindhyan and the Cuddapah systems.

A point of special interest is that Dr. Heron has suggested that the Delhis are not an Archaean system, but may instead represent a metamorphosed form of a Purana system, namely the Cuddapahs. In the latter case we should be left with only the Vindhyans, minus any portion that happens to be Cambrian in age, to occupy the space of 235 million years. In assessing the likelihood of the Vindhyans alone being sufficient for this gap we must remember that primitive chitinous fossils (F. Chapman, Rec. G.S.I., Ixix, p. 109,1935 ; M. R. Sahni, ibid., p. 458) have been found in the Suket shales, the topmost stage of the Lower Vindhyans. But we must remember also that the Peninsula of India is accustomed to long spells of relative inactivity as a land mass, and that a break in deposition of say 100 million years would not be out of accord with the later history of the Peninsula.

It is obviously most desirable that some method should be found of assessing in years the age of the Cuddapah system in its original home, namely the Madras Presidency, in order to settle whether it is younger than the Delhis of Rajputana, or is instead the equivalent thereof. ${ }^{2}$

1 Perhaps a comparison of the variations in the usage of the term "Huronian" would have been apter.

${ }^{2}$ As far as I know there are no pegmatites intrusive into the Cuddapahs, the principal intrusives being basic sills. 
In fact to settle the age of the Cuddapahs-whether they are younger than or are the equivalent of the Delhis-is more important to the understanding of the pre-Cambrian stratigraphy of the Peninsula of India than to determine the absolute ages of the Archaean systems below the Delhis. And as the next province on my list for discussion happens to be Province No. 5-Rajputana-Gujarat-I should be extremely grateful to Professor Holmes, or to any other student of radio-active methods, if the answer to this question could be forthcoming quickly.

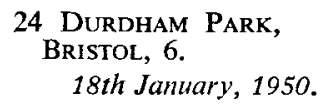

L. L. FERMOR.

\section{OCEANIC MEANDERINGS}

SIR,-D During the first world war the slogan used to be-Join the Army and see the World; Join the Air Force and see the Next. In the second war even ordinary citizens were allowed reasonable opportunities for extra tellural exploration. Now we are enjoying a lull during which various Air organizations have perfected the means of conveying a body around the world at high speed with unique opportunities for seeing nothing under conditions of considerable discomfort.

I have recently made such a journey around the world and, excluding my objectives which were a tour in Papua and a visit to Melbourne and New York, the scenic value of my trip was confined to a view from a great height of the Arabian desert, an eight-hour stop at Honolulu, and about two hours of the crossing from San Francisco to New York. For the rest, the solid world was obscured either by cloud, darkness, or oceans. The Pacific and Atlantic crossings were uneventful; the former took two days and was complicated by Saturday, 10th December repeating itself, the latter only five and a half hours - thanks to a 150-mile an hour tail wind at 20,000 feetbut even these were hours of darkness.

These immense oceans have an irresistible fascination and as the aircraft winged its way above the deep blue expanse bending out of sight beyond the curving horizons, one pondered on their significance and past history. I, personally, like so many of us have been through the early enthusiasms for the Wegener hypothesis and have come out at the other side. To my mind there is no acceptable case for the Atlantic and Indian Oceans being other than submerged sectors of a once continuous continental mass though traversed by geosynclines and orogenic systems of various ages with a pattern comparable to that of the present land areas. The Pacific is less simple but, even in this case, if we free our minds from prejudice and take stock of the evidence critically there are many geological pointers to this great ocean being a foundered area of ordinary continental character, perhaps traversed by fold systems and certainly subject to undulations of the ocean bottom on a large scale.

I write this letter not to expound and document my present point of view but to call attention to a considerable body of new evidence which is accumulating on the problems of oceans. The basis of the theory of the permanence of oceans, including the Pacific, is being badly shaken and the time is coming for a new stocktaking with many new facts and changed ideas to work on.

The hypothesis of permanence of oceans is founded partly in very insecure geological speculation and partly on the geophysical deduction that there is an essential difference between continents and oceans, thereby erecting the sialsima fantasy. Geologists have been reluctant to admit that fold systems, and therefore their flanking continents, can continue into the oceans beyond the last point seen; if Fiji, for example, had not chosen to exhibit itself the 